\title{
An Existential Crisis? \\ Freedom, Tolerance, Solidarity, Peace; \\ Or, Why Europe is Valuable*
}

\author{
¿Una crisis existencial?
}

Libertad, tolerancia, solidaridad, paz; o por qué Europa es valiosa

Joxerramon Bengoetxea

University of the Basque Country (UPV/EHU)

joxerramon.bengoetxea@ehu.eus

doi: http://dx.doi.org/10.18543/ced-59-2018pp115-137

Contents: I. Introduction.-II. The gist of the European project: institutional innovation and uniting peoples.-III. Two speeches on Europe's existential crisis. - IV. United in Diversity.-V. Diversity and Varieties of Pluralism.-VI. The centrality of the individual, the value of freedom.VII. A pluralist normative universe in Europe.-VIII. Conclusion: A normative proposal - Five steps of hermeneutic pluralism.-IX. References.

\begin{abstract}
This paper addresses Europe's existential crisis. It does so by suggesting that, notwithstanding the relevance of the institutional design, the essence of the project of European integration is persons and peoples rather than states. It then discusses two speeches of important personalities speaking about Europe's existential crisis. Next, it deals with the question of diversity since the motto of the failed constitutional treaty was precisely "united in diversity". But this requires explaining the centrality of the individual in practical reason, and the importance of normative systems. The centrality of the individual, related to the value of freedom, is then placed in the context of plurality and diversity, directly addressing the theme of backlash forces in Europe through a map of such plurality in Europe; the socalled multiculturalism or ethno-religious pluralism. The paper concludes by suggesting a version of cosmopolitanism, hermeneutic pluralism, as the normative position to address the balance between individual freedom and solidarity or between "persons" and "peoples".
\end{abstract} ism.

Keywords: European integration, cosmopolitanism, existential crisis, plural-

Resumen: Este artículo aborda la crisis existencia europea. Lo hace sugiriendo que, sin desatender la relevancia del diseño institucional, la esencia del

* Recibido el 15 de enero de 2018, aceptado el 9 de mayo de 2018. 
proyecto de integración europea son las personas y los pueblos, más que los estados. Partiendo de esa premisa, aborda dos discursos de importantes personalidades hablando sobre la crisis existencial europea. Seguidamente trata la cuestión de la diversidad en tanto que el lema del tratado constitucional fallido era, precisamente, "unidos en la diversidad". Sin embargo, esto requiere explicar la centralidad del individuo en la razón práctica, así como la importancia de los sistemas normativos. La centralidad del individuo, vinculada al valor de la libertad, se sitúa entonces en un contexto de pluralidad y diversidad, abordando directamente la cuestión del auge de los movimientos reaccionarios partiendo de un mapa de esa pluralidad en Europa; el llamado multiculturalismo o pluralismo etno-religioso. El artículo concluye sugiriendo una versión del cosmopolitismo, el pluralismo hermenéutico, como una posición normativa para tratar el equilibrio entre la libertad individual y la solidaridad entre las "personas" y los "pueblos".

Palabras clave: integración europea, cosmopolitismo, crisis existencia, pluralismo.

\section{Introduction}

In the space of six months, under the impact of Brexit, the Trump presidency in the US and the refugee crisis, Globernance organized two interesting workshops concerning crucial aspects of Europe as a project. In June 2017, the subject was "The European Crisis of Politics: Ethno-religious Pluralism and the Rise of Radical Populism and Far-Right in Europe". In December 2017, the theme was "Europe's Refugees". Although the issue of refugees is one of the key points in the Far-Right agenda, closely related to the rise of populism, this contribution deals mostly with the challenges these themes bring to the very core of European integration, giving rise to what has been referred to as an "existential" crisis.

This paper aims at contributing to an understanding of the existential crisis. It does so by suggesting that, notwithstanding the relevance of the institutional design, the essence of the project of European integration is persons and peoples rather than states. It then discusses two speeches of important personalities speaking about Europe's existential crisis. Next, it deals with the question of diversity since the motto of the failed constitutional treaty was precisely "united in diversity". But this requires explaining the centrality of the individual in practical reason, and the importance of normative systems. The centrality of the individual, related to the value of freedom, is then placed in the context of plurality and diversity, directly addressing the theme of the workshop by providing a map of such plurality in Europe, so-called multiculturalism or ethno-religious pluralism. The 
paper concludes by suggesting a version of cosmopolitanism, hermeneutic pluralism, as the normative position to address the balance between individual freedom and solidarity or between "persons" and "peoples".

\section{The gist of the European project: institutional innovation and uniting peoples}

"We are not forming coalitions between States but union among peoples". Jean Monnet's dictum ${ }^{1}$, that Europe is not about coalescing States but rather about uniting persons, goes to the heart of the European Project, the contrast between institutionalized understanding of the EU as formed by its Member States, on the one hand, and the prominence of persons as the source of legitimacy, popular sovereignty. It can thus be seen as an expression of ambition, an aspiration. But it probably begs two important questions. One is the federal question: you cannot unite people by imposition or diktat, you need an institutional design, you need to start somewhere, perhaps forming coalitions between States, institutional innovation. The other is the understanding of peoples. The founding Treaties spoke and speak of the project of "an ever closer union" among the peoples of Europe, not among the states of Europe or even the citizens of Europe. The items that unite are peoples, and states are, at best, their instrument for union. Peoples are prior to the states. Indeed, the composition of European peoples at the turn of WWII did not match the European states; and arguably, does not do so yet. European integration will falter if the aim of uniting persons, and peoples, is dimmed, and the focus is only set on states.

Uniting citizens is an ambitious endeavour involving the creation of public and institutional spaces, allowing for the development of a shared cultural and political identity, expressing and organizing solidarity through means of redistributive institutions through individual contributions and taxation, devising forms of self-determination where the people, the citizens, can govern themselves democratically. This is aspirational. It took nation-states centuries to develop in this sense; some of them never really did, and some peoples have started to face up to the challenge of democratic nation-state building precisely at the historical moment when European integration claims much of that ambitious project for itself. Whenever this project is questioned and turned around in favour of States and their governments, an existential crisis follows. Or, at least, it follows for European

1 Jean Monnet, "Nous ne coalisons pas des Etats, nous unissons des hommes" Speech given at the National Press Club, Washington DC, 30 avril 1952. 
integration. Not so for nation-states resisting integration. They tend to consider integration as a challenge to their own project of uniting their (own) nationals, their own people. Some versions of populism and nationalism feed from, and into, this position. The existential crisis for the nation-states comes when European integration is presented and conceived as the cosmopolitan project uniting European citizens, because that is precisely what nation-states historically purported to achieve at the national level. We can see this dialectic tension at play in the current European predicament, starting with the financial and economic crisis that erupted a decade ago, right after the sub-prime and banking crisis of the US.

In this dialectic, the thesis is that Europe is about uniting persons; the antithesis is that nation-states are about uniting citizens, the synthesis is that the only way states can unite their citizens is when these citizens federate and govern themselves at the European level through institutional structures and procedures that go very far beyond the mere coalition of States. Thus, European integration is about an institutional design for uniting persons and peoples.

European integration is largely about institutional experimentation. It has remarkably developed important constitutional features like shared normative competences, spanning over many matters where Member States have ceded sovereign powers, competences that override and take primacy over internal laws. It has generated a legal order of its own, with directly applicable instruments subject to judicial review, and with individual rights guarantees in a complete system of judicial remedies. It mostly respects the federal understanding that underlies its composite polity through constitutional principles like attributed powers, subsidiarity, proportionality, judicial dialogue through preliminary references by the ordinary judges of EU law, the idea of a single administration-as opposed to the parallel state and federal administrations in the US - Member States' formal equality, respect for national (and regional) constitutional identities. It has developed its own budget and resources, although direct taxation of physical and legal persons is still pending. Its law-making procedures are formally democratic and there is a sui generis separation of powers with some form of checks and balances, in a tension where Parliament is destined to prevail over Council, but not yet. In spite of the failed ratification of the Treaty establishing a Constitution for Europe, the EU is a system of public institutions with sufficiently extensive powers to constitute a discrete political community ${ }^{2}$.

2 Turkuler Isiksel, Europe's Functional Constitution. A Theory of Constitutionalism Beyond the State (Oxford: OUP, 2016): 71. 
From the point of view of law and legal systems, the EU is comparable to any federal legal system. European Integration has been thoroughly innovative from the perspective of legal theory and regulation. To mention but one example, we can think of its most characteristic instrument, the directive, as a mechanism for shared regulation, and the idea of co-legislation, between the federal and the state levels. In some areas, it legislates directly replacing internal regulation, by the instrument called "regulation". In others, it harmonizes member state legislations and, yet in others, it only seeks, cautiously, to approximate their laws. The role of the Court of Justice, through its dynamic interpretation of the Treaties is noteworthy ${ }^{3}$.

And, in liberal terms, the EU system ensures individual liberty, the freedom of citizens and judicial review over the exercise of public power. But does this, in and of itself, provide sufficient legitimacy and good reasons to obey and assume obligations other than through the fear of sanction? Liberal, rights-oriented legitimation is necessary, but is it enough? Under a constitutional system where norms are the practical understanding of a community of norm users, rather than norm-makers ${ }^{4}$, compliance would be secured if those norms were to be seen as our own laws. Thus arises the alternative source of obedience, democracy, where citizens govern themselves. This legitimation highlights a system of collective self-rule or popular sovereignty, in the best republican tradition. These two sets of questions provide the two ideal types of legitimacy in the polity: liberalism $\mathrm{v}$ republicanism. Liberal and republican forms of legitimation might still miss an important point: when do we want to see ourselves as a people, as a demos, under what conditions de we wish to build a polis in order to pursue the common good? In what sense are the citizens of the EU governing themselves? Is there a people of Europe? Where is this European demos? An additional source of legitimacy is then necessary, in a system where republican democracy and liberal constitutionalism are in the process of finding accommodation beyond the state ${ }^{5}$.

The functionalist answer to the source of legitimation is to devise an institutional setting for decision-making capable of delivering results, out-

${ }^{3}$ For an overview of the most relevant recent works on the Court, see Joxerramon Bengoetxea, "Text and Telos in the European Court of Justice", European Constitutional Law Review, Volume 11, Issue 01 (2015).

${ }_{4}$ The contrast between norm-users and norm-givers is a key contribution of the late Neil MacCormick, in his Institutions of Law (Oxford: OUP, 2007).

5 See, amongst others, Joseph Weiler, "Does Europe Need a Constitution? Demos, Telos and the German Maastricht Decision”, European Law Journal, Volume 1, Issue 3 (1995): 219-258. 
puts $^{6}$, such as economic progress, social and territorial cohesion, free movement, the single market, fair competition, consumer protection, economic union, high quality employment for all, social inclusion and combatting inequality, an area of freedom, security and justice, a common foreign policy, cooperation with third countries towards their development or sustainable development. These are all very important objectives, in themselves. There is little doubt that a well-functioning market, where commerce is carried out smoothly, and operators are dealing in fair competition, or a working legal system, based on the rule of law, are all crucial for any society to prosper peacefully. Creating a stable common currency in a monetary union is a step further, towards the integration of the economies. But if the results are not (perceived to be) satisfactory or if they are contradictory, then this form of legitimation fails, and retreat to the nation-state is seen as a panacea, as populist parties will be keen to stress.

Much of the pro-Brexit politics follow this pattern, showing dissatisfaction with the outputs delivered by the EU from the point of view of the single market and one of its key dimensions, the free movement of persons, and a strong dislike for the body that is entrusted with the application and interpretation of the law of the single market, the Court of Justice of the $\mathrm{EU}^{7}$. Retreat to the nation-state is then presented as a solution: the state takes back control of the free movement of persons, because Europeans are not trustworthy ${ }^{8}$. But the concept of the single market is systemic and holistic, all the factors of production are seen as un-severable, and if a State leaves the EU, it leaves the single market, and it will need to rebuild the market nationally. The EU was being criticized for not delivering its objectives, but it might be that the nation-state dreamt by the Brexiteers will not deliver either. Failing the single, common market, the patriotic and populist discourse of the Brexiteers can then provide an alternative panacea to keep people together, building on visions of a free society, a more caring welfare state, a protection of the "us" from the threats of the "them"

As regards the EU, if its very foundational objectives, as stated in Article 3 TEU, are not delivered or are seen to be failing, then its output legiti-

${ }^{6}$ On output legitimacy, see Fritz Scharpf, Governing in Europe, Effective and Democratic? (Oxford: OUP, 1999).

${ }^{7}$ As an illustration see the contrasting understandings of Brexit in the UK, even by its top officials. In the words of David Edward, "Just read the Brexit white paper, which would reduce the sovereignty of parliament to a rubber stamp. They want power for the government to alter statutes and that is Charles I.", in The Guardian, 13 June 2017.

${ }^{8}$ See Samuli Hurri, The Birth of the European Individual (New York: Routledge, 2014).

9 See Juhn Judis, The Populist Explosion, How the Great Recession Transformed American and European Politics (Columbia Global Reports, 2016); see also, by the same author, "Us v Them: The Birth of Populism" in the long read, The Guardian, 13 October 2016. 
macy based on progress will fail and an added existential dimension seems necessary to explain why we might want to share our destiny in Europe. Perhaps then, the project of uniting peoples and the aspiration to materialize values like tolerance, solidarity, peace, even love, understood in a sense close to brother- or sisterhood, are after all the necessary vision to sharing a community ${ }^{10}$. If this vision fades away we no longer know why we should want to be together and build a community towards the common good, other than by fear of sanction, and when this happens, we face an existential crisis. But are these values possible in the light of diversity and plurality, in the light of multicultural societies?

\section{Two speeches on Europe's existential crisis}

George Soros and Jean-Claude Juncker, two powerful men with the capacity to make the news in the European public space, have recently made important speeches in this regard. In September 2016, in the wake of the British vote to leave, the president of the European Commission, JeanClaude Juncker, pictured the European Union as facing an "existential crisis" 11 . Juncker gave his annual state of the Union address to the European Parliament, where he announced a raft of economic and security plans in the search for common ground between the Member States. The EU executive hopes to find the elusive common ground with a plan to boost the EU's infrastructure fund by increasing its value to $€ 500 \mathrm{bn}$ ( $£ 425 \mathrm{bn}$ ). Juncker also pressed for speedy implementation of the agreement to create an EU border and coastguard to ensure better control of migrants arriving from the Middle East and Africa. "People in Europe want to know if the political elites are capable of restoring control over events and processes which overwhelm, disorientate, and sometimes terrify them. Today many people, not only in the UK, think that being part of the European Union stands in the way of stability and security".

By expressing his concerns from the perspective of European political elites Juncker, who has been one of the longest-serving prime-ministers of any EU Member State, was paradoxically placing himself not in the position of the Commission but rather in the position of the national governments. He was on the side of the antithesis: it is for nation-states to unite citizens and the EU must not stand in the way. In his view, controlling im2001).

${ }^{10}$ See Zenon Bankowski, Living Lawfully. Love in Law and Love in Love (Springer,

11 https://www.theguardian.com/world/2016/sep/13/jean-claude-juncker-eu-is-facingexistential-crisis 
migration and terrorism, injecting funds for infrastructure seem to be the key.

A few months later, George Soros gave a speech at the Brussels Economic Forum ${ }^{12}$, where he also mentioned the existential crisis. "The European Union is now in an existential crisis ... . Most Europeans of my generation were supporters of further integration. Subsequent generations came to regard the EU as an enemy that deprives them of a secure and promising future ... . The European Union was meant to be a voluntary association of like-minded states that were willing to surrender part of their sovereignty for the common good [but]... After the financial crisis of 2008, the eurozone was transformed into a creditor/debtor relationship where the debtor countries couldn't meet their obligations and the creditor countries dictated the terms that the debtors had to meet. By imposing an austerity policy they made it practically impossible for the debtor countries to grow out of their debts. The net result was neither voluntary nor equal". In Soros' view, this loss of trust in the EU has paved the way for support for anti-European political parties. "Now we need a collaborative effort that combines the topdown approach of the EU institutions with the bottom-up movements that are necessary to engage the electorate.... Instead of a 'multi-speed' Europe we should aim for a 'multi-track' Europe that would allow member states a wider variety of choices. This would have a far-reaching beneficial effect." Soros welcomed a German idea to cut European funds aimed at reducing income inequalities at the regional level for those countries disrespecting the rule of law. Soros said Europe needs to overcome the current "existential crisis" by fighting together against the rise of anti-European sentiment, xenophobic feelings and surrounding "hostile powers: Putin's Russia, Erdogan's Turkey, Sisi's Egypt and the America that Trump would like to create if he could, but can't".

Soros comes closer to the synthesis where uniting citizens, ensuring a secure and promising future and a common good is something that cannot be done top-down only, by the EU institutions coalescing the Member States, but must also be done bottom-up, by movements of citizens engaging the electorate. But he is not fully there yet: the Common Good is certainly a value of the polis, but in his picture, this still seems to be delivered by the Member States, fighting together against populism and hostile powers. The missing part, in order to achieve synthesis, is the perspective of the citizens, of the persons governing themselves through common institutions to achieve the common good, expressing solidarity to others, dis-

12 https://www.cnbc.com/2017/06/01/soros-says-the-european-union-is-now-in-anexistential-crisis-surrounded-by-hostile-powers.html 
playing tolerance to those who dissent and defending the ultimate value of freedom of the person. Education and the consolidation of open and public social spaces of interaction and communication are both key factors for the dissemination of these values ${ }^{13}$. These are the missing link, again, to ensure a shared sense of community, the project of uniting peoples and the aspiration to materialise values like tolerance, solidarity, peace, love ...

\section{United in Diversity}

This contribution is seeking to discuss one possible explanation for this existential crisis, the loss of the shared vision of community, with the dimension of individual freedom, the dimension of tolerance-respect and recognition - and the loss of the more engaged, additional dimension of solidarity, in the context of pluralism, which the workshop calls ethno-religious pluralism. Even the loss of the more engaged dimension of love, understood as the recognition of an imminent dignity and humanity in all persons, the feeling of friendship - sisterhood or brotherhood - and the necessary harmony of biodiversity in nature, seeking the sustainability and balanced development of the planet Earth. As anticipated by the above discussion of Jean Monnet's vision of uniting peoples rather than forming a coalition of states, there is an issue with the notion of peoples and the relationship between peoples and persons. Peoples are formed by individuals, by persons or by citizens, grouped in communities, and these social groups or communities can take different forms. In these times of existential questionings for the dream of uniting Europeans, it might be advisable to reinstate the values upon which European integration is based. Two steps are necessary for that purpose. First, we need to identify the values expressed in the Treaties, relating them to the values of freedom, tolerance, solidarity and love, and second, we need to locate these values in the context of pluralism and diversity.

The Union's aim is to promote peace, its values and the well-being of its peoples. This is the text of Article 3 (1) TEU. The values of the EU are expressed in the Charter of Fundamental Rights of the EU, and in Article 2, and throughout the Treaty of the European Union, and largely, the Treaty on the Functioning of the EU. Article 2 TEU states the values upon which the Union is founded: "respect for human dignity, freedom, democracy,

${ }^{13}$ UNESCO's work in this sense is noteworthy. See, for example, A Sense of Belonging, CIDREE/UNESCO (1993), Guideline for values for the humanistic and international dimension of education and Tolerance: The Threshold for Peace, UNESCO (1994), A teaching/ learning guide for education about peace, human rights and democracy. 
equality, the rule of law and respect for human rights, including the rights of persons belonging to minorities". It goes on to add that these values are not exclusive but common to the Member States. The interesting addition is that these values operate "in a society in which pluralism, non-discrimination, tolerance, justice, solidarity and equality between women and men prevail". Assuming that these are also essential values, the list of values, combining Article 2 and Article 3(1) TEU would thus comprise:

- Peace

- respect for human dignity

- freedom

- democracy

- equality

- the rule of law

- respect for human rights

- respect for the rights of persons belonging to minorities

- pluralism

- non-discrimination

- tolerance

- justice

- solidarity

- equality between men and women

- the well-being of its peoples.

This compound of values can also be seen as a modern version of Kant's universal hospitality, as part of his perpetual peace ${ }^{14}$. Respect for nature is absent from the list, but it can be read into it since "the well-being of its peoples" surely encompasses a harmonious relationship with nature and is incompatible with environmental degradation. If these values were to be taken seriously by the EU, i.e., by its people, the Member States, and the EU institutions, the risk of falling into an existential crisis would be considerably diminished. One of the salient categories of value-tolerance, non-discrimination, equality, respect for the rights of persons belonging to minorities ${ }^{15}$, respect for human dignity and, most saliently, pluralism - has a lot to do with the subject of the seminar, i.e., the question of ethno-religious pluralism in multicultural societies, which brings us to the second step.

14 Immanuel Kant, Perpetual Peace, A Philosophical Sketch (1795).

15 We leave aside the discussion of the adequacy of the expression "belonging to minorities". The thought that any person might belong to a group is hard to reconcile with the notion of freedom and human dignity. 


\section{Diversity and Varieties of Pluralism}

As regards the second step and building again on Jean Monnet's vision, uniting peoples, from a different prism, we need to underline the choice of the term "union", or "uniting", which is very telling and spot-on. Uniting is not unifying: uniting is here understood as bringing together, implying togetherness, companionship, team spirit, striving to constitute a pluralist demos, whereas unification is a process of making oneness, unity in a strong sense. Union and federation can easily go hand in hand, but unification seems to carry a larger and more demanding enterprise, that of uniformizing, which amounts to eliminating difference. Uniting persons is not as hazardous as unifying them, and even less so than uniformizing them. Monnet's motto, "union of peoples" is very much in line with the motto of the failed constitutional Treaty, i.e., "united in diversity". By contrast, the motto that would correspond to unification would be "union and no diversity" and the motto corresponding to uniformisation could be "creating sameness through unification". A union in diversity and a union of the diverse respects that diversity, and this is precisely the key to address multiculturalism, ethno-religious pluralism or cultural and constitutional pluralism ${ }^{16}$.

Tolerance, recognition, respecting diversity and the rights of persons belonging to minorities are indeed primary values, but they must not lead to the denial of equally primary values like freedom or human dignity. All these values should be systematized into a coherent whole, and normative systems of practical philosophy-ethics, religion, politics, law - aspire to reach a reflective equilibrium: displaying respect and solidarity to those who are diverse and different but make up and share one same civic project requires that each of the culturally identifiable groups respects the integrity and dignity of the person, of each of their members and that they equally

16 This is the question of the demos constituted by several peoples. As Daniel Innerarity ("Does Europe Need a Demos to Be Truly Democratic?", in London School of Economics, LEQS Paper No. 77 (2014) has put it, "a demos is "a group of people, the majority of whom feel sufficiently connected to each other to voluntarily commit to democratic discourse and to a related decision-making process' (Cederman 2001, p. 224). When there is identification, we can expect coherence, shared objectives, and a propensity for solidarity; where there is none, there is generally division and an inability to build anything in common. "If there is no demos, there can be no democracy" (Weiler, 1999, p. 337; Weiler, Haltern and Mayer, 1995). Without demos, there is no confidence, recognition, solidarity or reciprocal friendliness, which are all values that are essential for democratic coexistence." This contribution's insistence on the idea of love establishes a dialogue with Innerarity's idea of friendliness. One of the two values, love and/or friendship, is essential for the purpose of uniting persons, while respecting their difference. 
respect the dignity of those who are not their members. Embracing the dignity of humanity in this sense could then be extended to a respect and appreciation for all living beings and to nature, and this can be understood as an act of love, a sense of immanence and spirituality. These are all fundamental values that inspire the European Project of integration and Monnet's Cosmopolitan vision of uniting persons.

There are three types or expressions of pluralism in Europe: (1) cultural pluralism, usually portrayed as multiculturalism, or ethno-religious pluralism in the terms of the Workshop, (2) legal pluralism or diversity of legal orders and (3) constitutional pluralism. Multiculturalism in Europe, traditionally linked to sociologically complex societies with an increasing number of subcultures or to ethnic and religious diversity, language minorities, regional and national identities is now increasingly the result of immigration and religious diversity. This rich plurality brings along not only a diversity of lifestyles, beliefs, mores, languages, looks, fashion, attire, gastronomy and the like, but also social (religious or moral) norms concerning crucial aspects like family relations, marriage forms and rights and duties of spouses, divorce and many other matters that can be considered forms of legal norms or law, and that often affect the autonomy of the individual. The result of this cultural diversity, in the normative domain, is something close to what legal sociologists, anthropologists and comparativists call 'legal pluralism', in debates where the State and its official reaction to such diversity occupies a prominent role.

However, the transformations of the State in the European Union and the new transnational and global legal phenomena give rise to new forms of pluralism that need to be accounted for. It is worth analysing the way in which such diversity of social and legal norms is integrated into a new European system protecting fundamental rights and claiming to have a final say on the many, ever-growing, areas of European legal concern. States and their constitutional courts remain as key, but no longer sole and perhaps no longer ultimate custodians, and this new polyarchy gives rise to new pluralist discussions labelled under the term constitutional pluralism. Here is a fine question for social scientists and methodologists interested in the law, but it also encompasses issues of normative and constitutional prognosis as to whether for example a European People, a constituent demos, will eventually conform giving rise to a new discussion of pluralism and monism which it might be interesting to compare to and contrast with the federal constitutional foundation of the USA. The current context of European crises where these different forms of pluralism are interacting makes it necessary for scholars and citizens to understand diversity within Europe, to analyse cultural plurality and the legal claims and challenges that it generates on the legal system and on institutions at all levels: local, regional, state and 
supranational, and to see how the different responses at these levels themselves create a new pluralistic picture ${ }^{17}$.

\section{The centrality of the individual, the value of freedom}

This paper argues in favour of the values of freedom, tolerance, solidarity and love as pertaining to different, but complementary, dimensions of normative discourse within practical philosophy: law, politics, ethics, even religion. Each of the proposals made from such normative systems of practical philosophy is to achieve a reflective equilibrium and a coherent set combining respect for the rights of persons belonging to minorities and respect for individual freedom and human dignity. There are important interactions between these dimensions, and their correlative values are not always easy to sort out and correlate with only one of the normative systems or dimensions, but one can adopt an intuitive approach to identify the focal value of each of those dimensions. Practical Philosophy largely provides answers to the question: what is to be done? The context of action becomes crucial: what is to be done in a particular context. Different dimensions of practical reason or practical philosophy address this normative challenge: law, politics, ethics, religion ${ }^{18}$.

${ }^{17}$ I have dealt with these issues more in depth in my "Rethinking EU Law in the Light of Pluralism and Practical Reason" in Miguel Maduro, Kaarlo Tuori and Suvi Sankari (eds.), Transnational Law (Cambridge: Cambridge University Press, 2014).

18 Religion is a system of practical reason in, at least, two ways: as a form of morality, religious ethics includes directives on behaviour towards others, and as system of beliefs about man, about divinity and about the universe. These beliefs are held to be true and often revealed through Scripture, as in the case of the three main religions based on a Book. This fact leads to a special type of dogmatic reasoning, based on the premises of the Scripture. The image of the divine spirit is often essential for religious understandings of personhood and social behaviour. Thus, if God is conceived as a benevolent, omnisapient being, who can easily forgive the mistakes made by humans when trying to conceive of the divine, then a tolerant spirit might be based on religion: since humans are modest and limited in their perception and only God is perfect, this humility can inspire compassion and respect for different conceptions and interpretations of the divine and the good, and, along this spirit, a fruitful conversation of different creeds, respecting each other's claim to truthfulness can be made compatible with religious pluralism and with systems of belief that deny such divine dimensions. Theism, atheism or polytheism would surely be positions tolerated by a benign God. Forgiveness, peace, tolerance and love are thus religious values, as opposed to revengefulness, war, imposition and rage. The debate turning on the Christian heritage of Europe that took place during the Convention on the Future of Europe, where it was finally decided not to make special mention of the Christian component, could have taken other paths towards interreligious dialogue and pluralism. Joseph Weiler argued strongly in favour of such explicit mention in Un'Europa Cristiana. Un saggio esplorativo, (BUR Biblioteca Univ. Rizzoli, 2003) because 
In our advanced and complex societies, the diversity of normative outlooks nurtured by different and sometimes incommensurable values provide different answers to the question: what is the correct course of action in any given situation? ${ }^{19}$ How are we to interact in a social group? Traditionally, the groups have been the context where these practical questions have arisen, because human interaction is determined by coordinates of time and space and institutional realities. From the city-state of the polis to the post-Westphalian nation-state that culminates in WWII, the context has been municipal and national. But now the context is local, regional, statenational, European and international, in other words, local and global. But all practical philosophy systems address the question: what is to be done? The individual addressing this question is not an isolated being, but a social actor, "belonging" to a group, belonging in society, to a majority group or as the Treaty says, "belonging to minorities". The normative translation of these questions in the law, at the risk of simplification is: what are our rights and obligations towards others?

Rights and obligations in Europe are assigned to individuals. In a very important sense, Human Rights Culture is individualistic. But clearly, individuals are not noumenal or atomistic self-standing cultural or social units, and many of their rights and obligations become meaningless without the social, community or group dimension. The point is not that rights are vested in groups; "group rights" is a hotly debated issue. The suggestion is, rather, that (some) individuals conceive of and lead more valuable lives through their membership of or in groups ("rights through a group") rather than being left on their own to devise their vision of the good. We can still be normatively individualist and stick to individual freedom and autonomy as the ultimate value, and yet remain cognitively social or communitarian. It is also conceivable that individually, persons opt for a collective expression of their conceptions of the good and their view of life, deciding and acting as a community, and if this is a free will, then the decision is equally respectable. European legal culture tends to be individualistic in a normative sense, but Europe is characterized by diversity, plurality and complexity in a cultural and social sense. The idea that Europe is about uniting peo-

omitting any reference to Christianity from the European constitution would unjustly favour secular constitutional traditions over religious, or "established" constitutional traditions. Weiler's understanding of tolerance is in line with the main thrust of my paper: the "discipline of tolerance"-i.e., recognizing that the "other", whether Christian or Muslim, secular or religious, is denying some reality central to one's own understanding of the world, while respecting that other as an equal despite this difference - should be the ethical core of the European project.

19 See Neil MacCormick, Practical Reason in Law and Morality (Oxford: OUP, 2009). 
ples thus needs to address the question of who are those peoples and what their relation is to the individuals that make them. The remaining part of this contribution addresses these questions.

\section{A pluralist normative universe in Europe}

There are over thirty widely used languages in the EU, not all of them official; a handful of major World religions together with a plethora of nonreligious and anti-religious beliefs, as well as a rich collection of traditions, histories of peoples and groups of ethnic and national minorities. Some of these territorial-national minorities often, not always, happen to be majorities in their territories and other times they are territorially separated from the State of their national identity. This is the case, for instance, of Hungary and the Magyar in Romania, or of Serbian Kosovars and Muslim Serbians in Kosovo and Serbia, a thorny reminder of the complex linguistic, ethnic, national and religious mosaic in the Balkans. Others are non-territorial minorities (the Roma or gypsies), and, scattered mostly in the major metropolitan areas, there are communities of immigrants and urban subcultures.

Cultural diversity in Europe therefore springs from a diversity of sources:

- National, cultural or linguistic minorities e.g. Serbians in Kosovo after independence in 2008, Kosovars in Serbia before 2008, Basques or Kanaks in France, Catalans and Basques in Spain;

- Immigrant groups with organised religious claims, e.g., Muslims in most European states, Jews in some European states ...

- Non-territorial ethnic minorities with a special way of life, e.g., Roma in some European states;

- Other heterogeneous groups: sub-urban minority groups and subcultures, rights-groups claiming accommodation and recognition of their difference, based on gender, sexual orientation, disabilities, lifestyles, ideologies, age ... in all European states;

- Other cases that are hard to classify, e.g., Gibraltarians in the UK resisting Spanish sovereignty claims and maintaining privileges under the Commonwealth and the Crown or Russians in Latvia.

This is a pan-European classification. The classification may differ in each of the European Member States. It will be different in Portugal, in the UK, and within the UK, it will be different in Scotland, Wales or Northern Ireland, or in Finland, in Slovakia, in Latvia, in Austria or in Greece, to name but a few. In other parts of the world, multicultural studies focus on other major sources. In the USA's melting pot, indigenous peoples, immigrant communities and racial minorities get more attention than national 
minorities, often seen as diasporic, or else treated under the category of First Peoples; but in Canada, national minorities are clearly brought to the fore. In India, religious, cultural and national minorities, along with class stratification, are highlighted.

Multiculturalism calls for political accommodation by the state and/or a dominant group of all minority cultures and for coexistence between groups, by reference to race, ethnicity, religion, language, nationality or aboriginality. Studies of cultural diversity or plurality and normative proposals of multiculturalism draw from each of these different groups. On a practical reason or practical philosophy dimension, these groups all make social, political and legal claims on rights, policies and obligations in various ways. They all claim (official) recognition of their difference, non-discrimination and resistance to assimilation; they all aim at participation in social and political life of the wider organised society and call for a nuanced understanding of the principle of equality as non-discrimination and awareness to differencetreating like cases alike and not treating unlike cases alike. Depending on their identities and their perceived needs and interests, each of the identified categories of groups make specific claims (demand side):

- National minorities make territorial, cultural, linguistic claims, demands for devolution and self-government and for official recognition and constitutional accommodation;

- Religious groups claim respect, tolerance and freedom to pursue and practice their own, distinct view of the good;

- Ethnic minorities claim non-discrimination and equality and special measures of inclusion or positive discrimination;

- Indigenous people have special claims related to their territories and local knowledge and way of life;

- Non-territorial ethnic minorities make claims of cultural recognition;

- All groups generally claim non-discrimination, respect and support for their special social, cultural needs.

The role of the philosophy of practical reason is to study and critically assess them. This is the most difficult but adequate approach to the value of "pluralism": it tries to study and understand the types of claims and the responses-legal and political strategies, reasons and techniques-to those claims, and defers the evaluation of these debates to a latter stage. These claims for access, power, empowerment, recognition, tolerance, respect, equality are made before different institutions: legislatures, policy-makers, jurisdictions and administrations, and also before non-public organizations e.g. mass media, telecommunications, cultural industry, educational sector, labour environment, political parties, trade unions, NGOs. Public institutions, organizations, agencies and bodies with the authority to make general norms and 
determine public policies or to apply those general rules and generate individual norms responding to these claims in different ways (supply-side):

- Containing demands for difference, where a majority is supported when facing minority claims;

- Reinforcing equality as "uniformity" or assimilation, denying the relevance of difference;

- Reconstructing equality as non-discrimination, recognising a claimed difference;

- Granting special rights of representation for collectives, often seen as special privileges;

- Recognising and accommodating differences from reasonable accommodation to full blown pluralism and programs for inclusion;

- Mainstreaming the differences and encouraging a normative and communicative situation between majority and minority positions, either through legislative measures or judicial recourse to equity and exceptions.

All these responses take place at different levels and different institutions or legal strategies, e.g., adoption of general, universal norms or dispute resolution through litigation or alternative methods. The responses vary according to territorial-institutional perspectives. They have a lot to do with access to power and power sharing. Depending on the powers or competences assumed by each institutional arrangement, the types of demands and the types of norms and decisions adopted, the reactions vary greatly (institutional-governance levels):

- Local level, e.g., permits for the building or opening of a new mosque, family counselling services, school boards / normally accommodation $\mathrm{v}$ rejection takes the form of administrative decision; but other forms like mediation can also solve individual conflicts;

- Regional level: housing and social benefits, provision of health, taxes, education policy, infrastructures, cultural promotion, social inclusion policy / accommodation or containment can take the form of legally recognised and enforceable rights, or promotion policies; also, administrative decisions and judicial individual norms;

- Member State level: immigration, labour laws, justice, of course Human Rights constitutional control / legislative accommodation through universal norms, social and cultural policies, individual judicial decisions at highest courts;

- European level (very complex governance): harmonization of laws, free movement, internal market, non-discrimination directives, promotion measures and programs, but also judicial decisions. 
Multiculturalism and ethnoreligious pluralism can be seen as a comprehensive normative theory guiding public policy and decision-making in many different domains. These different responses are then also controlled, overseen or supervised by European supranational institutions by reference to commonly shared European values and standards as recognised by and interpreted from important Human Rights instruments (the standards for review):

- Council of Europe, European Convention of Human Rights, European Court, Venice Commission: depending on the existence of a European consensus there will be more or less margin of appreciation left to the states, e.g., special constitutional traditions like Turkish or French laïcité or radical secularism, or special Catholic culture in Italy;

- European Union institutions and the values of integration: the evercloser union of peoples, subsidiarity, margin of appreciations, harmonization, solidarity, loyalty and cooperation, mutual recognition, equal treatment;

- EU Charter of Fundamental Rights and Social Charter: Fundamental Rights, HR Agency;

- (Peace and) Security and Cooperation OSCE: the whole rationale of the democratization of Central and Eastern Europe;

- UN Legal Instruments, Conventions on Human Rights, individually and collectively understood, and UN soft law on Human Rights.

Interesting tensions and dynamics obtain as to the descriptive-interpretative question as to who is actually setting the standards and highlighting the values and as to the normative question of who should be setting those standards: local versus European or global. As mentioned above to the extent that a "European" consensus may have emerged, the local-meaning national-margin of appreciation will decrease and to the extent that the challenges at stake need to be and actually are tackled effectively at a wider regional European scale, the scope for subsidiarity and proximity of decision-making to the citizens will diminish.

We engage in the evaluation of these normative questions from the standpoint of critical discourse theory and of a new understanding of law and its legitimacy. The result of this complex situation of multiple forums or fora or public spaces of debate where multiple sovereign authorities are trying to find their way in this complex institutional patchwork is a diversity of normative claims. It is not only a question of who gets to interpret and decide on the extent of the competences (or powers), but the difficult question is, as Humpty Dumpty put it to Alice: "who is to be master", in other words, where sovereignty itself lies and whose normative standards are going to be followed. Is it, as the state-nationalists claim, on the side of the Member States or is it, as the European federalists claim, on the side of 
the EU? And what does it mean that sovereignty tilts in favour of the EU, other than it is the persons (citizens) and peoples of Europe who share their sovereignty at the European level? Looking at the cases where European supranational courts have reviewed UN Security Council resolutions on the basis of Human Rights or at the cases where the ECHR has controlled EU Member State's normative standards and practices or their wrongful implementation of EU policies, one might conclude that the question is rather who is to be the legitimate interpreter?

Take issues like the banning of political parties or the treatment of detainees and the recognition of certain fundamental rights to prisoners or the imposition of certain penalties and the definition of certain crimes. These issues might be less controversial within a homogeneous society or a seemingly consensual society where divergent voices do not get much media attention - according to the principle that national authorities know better and thus need a margin of appreciation - but they might be much more controversial and closely examined from a wider European perspective where such consensus is regarded with more scepticism-according to the need for European-wide standards on the core of the rights recognised.

And sometimes the local level, even in well-established democracies, might see this European control as offensive, like when important parts of public opinion in the UK push for a revision of the terms of their accession to the European Convention of Human Rights on the basis of their different local appreciation of the standards (UK Commission on a Bill of Rights).

\section{Conclusion: A normative proposal - Five steps of hermeneutic pluralism}

Having reached this point, we may ask ourselves: how do we then unite peoples and persons in Europe while recognizing their difference? How do we reach a normative constellation where persons and groups wish to live together, with respect for difference, while at the same time wishing to engage in a collective definition of the Common Good? We are now at ease with the thought that Heterogeneity and Diversity are structural features of the EU. In order to capture the full "diversity of pluralism" in Europe, and to obtain a coherent system with a reflective equilibrium between the values of the EU, we suggest a five-step hermeneutical roadmap. The roadmap is devised by combining both the descriptive and the normative approaches hermeneutically.

i. To begin with, and remaining at the institutional level, we need to bring in the wealth of pluralities at a vertical territorial axis. This is classical multi-level governance: from the local to the global. 
ii. Next, we need to examine the inclusiveness claims at each of these levels - from the local to the European - and ask ourselves whether important communities or groups might be excluded from each of the pluralistic mosaic of "the peoples" that want to unite; for instance, is this EU only a club of states or, even worse, of unitary nation-states? Are nation-regions or national minorities forced into the straightjackets of their Member-States such as Quebec in Canada, Scotland in the UK or the Basque Country and Catalonia in Spain?

iii. We would need to be aware of the fact that these territorial jurisdictions, at each level, are implicitly contested or challenged by legal pluralism at the level of norms or even normative orders that are competing if not as global regulators, at least in specific areas of social regulation (typically family law, but also commercial law) and at local, regional, national, state, transnational, supranational and international levels. This, again, raises the classical issue of legal pluralism, or the coexistence of normative orders that could be called minority legal orders. There is not only a plurality of norms, but also alternative fora and methods of dispute resolution at each of these levels.

iv. Then, we could continue on a horizontal axis of inclusiveness to study if there might be groups or collectives that are not territorially based but are neglected or ignored since they are under the sovereignty of the institutional bodies that do get formal representation. It might be that in new forms of governance the same type of stakeholders, elite regulators (repeat players) get to set the standards, because they are better mobilised or are consulted more regularly or are more powerful. We would find inspiration by theories of multiculturalism or inter-culturalism, even by more group-oriented communitarian theories to push towards inclusiveness and participation.

v. Finally, "the wind of freedom blows" within minorities as well; this inclusiveness must be carried deeper, as an ideal normative framework, to each of the communities claiming recognition of difference, enquiring how each of these groups is itself handling internal endogenous claims of difference and of participation and exercises of individual autonomy or personal self-determination (internal minorities).

This is where we reintroduce important values of liberalism and individualism as enshrined in most of our Human Rights instruments. Here, obviously, we are ideologically loaded in favour of the value of autonomy. In doing so, we also reintroduce popular mobilisations and claims for Human Rights, for participation and deliberative democracy, but also the supervision and control by the key European supranational institutions, the European Court of Justice 
and the European Court of Human Rights; and these are important aspects of the cosmopolitan vision of Europe. As regards Human Rights standards, social inclusiveness and solidarity, this seems to be the way to recapture the inspirational combined sovereignty of the abandoned constitutional treaty (which could have been reframed in this manner: We the Citizens and We the Peoples of Europe!). The Member States and the Autonomous Constitutional Regions will be recognised a margin of appreciation and subsidiarity according to local standards, but there will be Europe-wide supervision and control on the basis of any achieved consensus or acquis on agreed standards.

This fine balance could be carried through to the issues raised by cultural pluralism and accommodation and to the coupling of the economic and social constitutions. But Europe as a project covers other important domains, many of them related to the regionally perceived global risks: security agenda, environmental risks. But as regards other domains where competition and relocation are easier, such as economic or financial risks, the EU still has to take the lead, that is, coordinate. Many economic policy aspects like welfare politics, monetary, regional cohesion and fiscal solidarity are crucial areas for cooperation, coordination and harmonisation if Europe is to find the balance between the social constitution (now largely under Member State control) and the economic (monetary) constitution (now under EU control). Member State sovereignty and interests are, at the same time, the problem and the solution. When they insist on a coalition of state governments rather than the union of European peoples, when they lose sight of the values upon which the EU is founded, the values that give meaning and purpose to the very project of European integration, existential crisis follows.

\section{References}

Bankowski, Zenon. Living Lawfully. Love in Law and Love in Love, Springer (2001). Bengoetxea, Joxerramon. "Rethinking EU Law in the Light of Pluralism and Practical Reason", in Miguel Maduro, Kaarlo Tuori and Suvi Sankari (eds), Transnational Law, Cambridge: Cambridge University Press (2014): 145-169.

Bengoetxea, Joxerramon. "Text and Telos in the European Court of Justice", European Constitutional Law Review, Volume 11, Issue 01 (2015): 184-216, CIDREE/UNESCO. A Sense of Belonging (1993).

Hurri, Samuli. The Birth of the European Individual, New York: Routledge (2014). Isiksel, Turkuler. Europe's Functional Constitution. A Theory of Constitutionalism Beyond the State, Oxford: OUP (2016).

Innerarity, Daniel. "Does Europe Need a Demos to Be Truly Democratic?", in London School of Economics, LEQS Paper No. 77 (2014).

Judis, Juhn. The Populist Explosion, How the Great Recession Transformed American and European Politics, Columbia Global Reports (2016). 
—. "Us v Them: The Birth of Populism" in the long read, The Guardian, 13 October 2016.

Kant, Immanuel. Perpetual Peace, A Philosophical Sketch (1795).

MacCormick, Neil. Institutions of Law, Oxford: OUP (2007).

MacCormick, Neil. Practical Reason in Law and Morality, Oxford: OUP (2009).

Monnet, Jean. "Nous ne coalisons pas des Etats, nous unissons des hommes" Speech given at the National Press Club, Washington DC, 30 avril 1952.

Scharpf, Fritz. Governing in Europe, Effective and Democratic?, Oxford: OUP (1999).

UNESCO. Guideline for values for the humanistic and international dimension of education and Tolerance: The Threshold for Peace (1994).

Weiler, Joseph. "Does Europe Need a Constitution? Demos, Telos and the German Maastricht Decision", European Law Journal, Volume 1, Issue 3 (1995): 219258.

Weiler, Joseph. Un'Europa Cristiana. Un saggio esplorativo, BUR Biblioteca Univ. Rizzoli (2003).

\section{About the author}

Joxerramon Bengoetxea (Irun, Basque Country, 1963) is a Lecturer accredited as Full Professor at the University of the Basque Country (UPV/ EHU), where he coordinates the ehuGune programme, "rethinking together" (see https://www .ehu.eus/ehugune). Since 2015 he is General Secretary of the Basque Council of the European Movement (http://www.eurobask.org) and vocal of the Comisión Arbitral del País Vasco. Since 2005 he directs the International Master in Sociology of Law (official MA at the UPV/EHU since 2007), where he teaches a course on compared legal cultures and the doctoral subprogram in Sociology of Law within the program on examining globalization. He studied law and philosophy at the UNE and the UPV/ EHU, where he obtained his BA in Law (1986). He obtained his PhD in Law at the University of Edinburgh (1989), supervised by Professor Neil MacCormick, and completed his training at the Universität des Saarlandes and the European University Institute (Florence). He was the Attorney of Judge Edward at the Court of Justice of the European Union (1993-98 y 20022004) and vice-minister of Employment and Social Security of the Basque Government under the minister of Justice, Employment and Social Issues, Sabin Intxaurraga (1998-2001). His research and publications explore issues related to legal reasoning, theory, philosophy and sociology of European law, theory of European integration, political philosophy, European regionalism, transitional justice, legal pluralism, compared law and comparative legal cultures. Since 2012 is also an invited lecturer at the University of Bordeaux, where he teaches a course on Spanish constitutionalism and has been 
invited lecturer at the universities of Oxford (2001), Stanford (2012), Helsinki (2013) and Kansai (Japan, 2014). He was the scientific director of the International Institute of Legal Sociology (2005-7), in Oñati http://www.iisj. net and in 2010 he gained the Eusko Ikaskuntza-Laboral Kutxa prize in Humanities, Culture, Arts and Social Sciences (http://www.eusko-ikaskuntza. org), where he has been an active member since 1983.

\section{Sobre el autor}

Joxerramon Bengoetxea (Irun, País Vasco, 1963) es Profesor acreditado a catedrático de la Universidad del País Vasco/Euskal Herriko Unibertsitatea (UPV/EHU) donde coordina el programa ehuGune, "rethinking together" (ver https://www.ehu.eus/ehugune ). Desde 2015 es Secretario General del Consejo Vasco del Movimiento Europeo, (http://www. eurobask.org) y vocal de la Comisión Arbitral del País Vasco. Desde 2005 dirige el International Master in Sociology of Law (master oficial de la UPV/EHU desde 2007), donde imparte el curso sobre culturas jurídicas comparadas y el subprograma de doctorado Sociology of Law dentro del Programa sobre la globalización a examen. Estudió derecho y filosofía en la UNED y UPV/EHU donde se licenció en derecho (1986). Se doctoró en derecho por la Universidad de Edinburgh (1989) bajo la dirección de Neil MacCormick y completó su formación en las Universität des Saarlandes e Istituto Universitario Europeo. Fue letrado del juez Edward en el Tribunal de Justicia de la UE (1993-98 y 2002-2004) y viceconsejero de Trabajo y Seguridad Social en el Gobierno Vasco con el Consejero de Justicia, Trabajo y Asuntos Sociales, Sabin Intxaurraga (1998-2001). Sus investigaciones y publicaciones exploran cuestiones de razonamiento jurídico, teoría, filosofía y sociología del derecho europeo, teoría de la integración europea,filosofía política, regionalismo europeo, justicia transicional, pluralismo jurídico, derecho comparado y comparación de culturas jurídicas. Desde 2012 es además profesor invitado de la Universidad de Burdeos donde imparte un curso sobre constitucionalismo español y ha sido profesor invitado en las Universidades de Oxford (2001), Stanford (2012), Helsinki (2013) y Kansai (Japón, 2014). Fue director científico del Instituto Internacional de Sociología Jurídica (2005-07), de Oñati http://www.iisj.net y en 2010 recibió el Premio Eusko Ikaskuntza-Laboral Kutxa de Humanidades, Cultura, Artes y Ciencias Sociales (http://www.eusko-ikaskuntza.org) de la que es miembro activo desde 1983. 


\section{Derechos de autor}

Los derechos de autor (para la distribución, comunicación pública, reproducción e inclusión en bases de datos de indexación y repositorios institucionales) de esta publicación (Cuadernos Europeos de Deusto, CED) pertenecen a la editorial Universidad de Deusto. El acceso al contenido digital de cualquier número de Cuadernos Europeos de Deusto es gratuito inmediatamente después de su publicación. Los trabajos podrán leerse, descargarse, copiar y difundir en cualquier medio sin fines comerciales y según lo previsto por la ley; sin la previa autorización de la Editorial (Universidad de Deusto) o el autor. Así mismo, los trabajos editados en CED pueden ser publicados con posterioridad en otros medios o revistas, siempre que el autor indique con claridad y en la primera nota a pie de página que el trabajo se publicó por primera vez en $C E D$, con indicación del número, año, páginas y DOI (si procede). Cualquier otro uso de su contenido en cualquier medio o formato, ahora conocido o desarrollado en el futuro, requiere el permiso previo por escrito del titular de los derechos de autor.

\section{Copyright}

Copyright (for distribution, public communication, reproduction and inclusion in indexation databases and institutional repositories) of this publication (Cuadernos Europeos de Deusto, CED) belongs to the publisher University of Deusto. Access to the digital content of any Issue of Cuadernos Europeos de Deusto is free upon its publication. The content can be read, downloaded, copied, and distributed freely in any medium only for non-commercial purposes and in accordance with any applicable copyright legislation, without prior permission from the copyright holder (University of Deusto) or the author. Thus, the content of $C E D$ can be subsequently published in other media or journals, as long as the author clearly indicates in the first footnote that the work was published in $C E D$ for the first time, indicating the Issue number, year, pages, and DOI (if applicable). Any other use of its content in any medium or format, now known or developed in the future, requires prior written permission of the copyright holder. 